\title{
State financial resources as a tool for managing sustainable development of territories
}

\author{
Yulia Dolganova ${ }^{1}$, Natalia Istomina ${ }^{2 *}$, Alena Zaborovskaya ${ }^{2}$, and Venelin Terziev $^{2}$ \\ ${ }^{1}$ Georgi Rakovski Military Academy, 1504, Bul. Evlogi \& Hristo Georgievi 82,Sofia, Bulgaria; \\ University of Rousse, 7017, Studentska St. 8, Rousse, Bulgaria \\ ${ }^{2}$ Ural State University of Economics, 620144, 8 Marta/Narodnoy Voli St. 62/45., Ekaterinburg, \\ Russia
}

\begin{abstract}
The article presents quantitative evidence for the hypothesis that the level of economic development of Russian regions depends on the amount of financial resources allocated by the state. Based on the study of statistical data on territories related to border, coastal, inaccessible and enclaves, quantitative dependencies are identified and conclusions are drawn about the current practice and directions of development of the state regulation.
\end{abstract}

\section{Introduction}

A significant amount of scientific research is devoted to the issues of sustainable development of territories, including works covering various definitions of the concept of 'sustainability', in particular [1-3]. In a broad sense, 'sustainability'means 'the ability of a system to maintain a given state in the presence of external influences' [1]. With regard to the development of territories, we agree with the definition in which sustainability is considered as "such development of the economic, political, social and environmental sphere ... which ensures a balanced progressive development of the region as a whole, which should result in an improvement in people's lives" [2]. Sustainable development management (sustainability management) is an important component of the activities of government institutions and - in relation to the regions of the Russian Federation - is "a systematic and constructive activity carried out by institutions of state power and management, which... is based on the General principles of public administration in order to coordinate the interests of business entities, the region, the state and society" [3]. It is extremely important that in the framework of ensuring sustainable development management, the importance of coordinating the interests of various subjects is emphasized.

Ensuring the sustainable development of territories, on the scale of such a geographically extended state as the Russian Federation, is impossible without sufficiently active state intervention. From the financial point of view, such intervention is ensured by

${ }^{*}$ Corresponding author: n_istomina_usue@mail.ru 
providing inter-budget transfers from the Federal budget, as well as by making public investments in the regional economy.

From the point of view of the state, when implementing measures of state influence on the socio-economic development of territories in order to ensure their sustainable impact, the most important issue is the result of such influence. Indeed, the simple transfer of financial resources up to the level of territories is an unacceptable luxury in conditions of limited state budget funds and other sources associated with the state. Therefore, one of the directions of scientific research is to determine the results of state management of territorial development.

Sustainable development of territories is a task that is complicated by the problem of differentiation of the level of socio-economic development of states, a problem that is relevant not only for large countries of the world, including the Russian Federation [4], but also for much more compact states [5]. Recognizing the expediency of managing the development of the entire set of territories of the state, we consider it important to emphasize that special areas of state influence must be the territories that have a set of objective obstacles to achieve a level of sustainable development in dependently. In particular, there are four types of such territories: border territories, coastal territories, hardto-reach territories, and enclaves.

The purpose of the study is to determine the relationship between the financial flows of the state directed to the development of special territories and the economic growth rates of territories because of state influence.

\section{Methods and materials}

To identify the patterns presented in the results of the study, 7 regions of the Russian Federation were selected from the General population, representing the border regions (Leningrad region, Bryansk region), Primorye (Sakhalin region, Primorsky territory), hardto-reach territories (the Republic of Tyva, Kamchatka territory), and the Kaliningrad region as an example of an enclave territory.

The study of changes in the analysed indicators over time was carried outthrough the analysis of time series. Comparison of individual levels of a dynamics series allows us to draw conclusions about the development of the phenomenon under study. In the framework of this research, in particular, the growth rates of indicators were calculated, which were used to identify the connection between the volume of public funding and the growth of GRP in the region.

To analyse the ratio of various types of investments in the economy of the regions under consideration, a regression and correlation analysis was performed.

Correlation analysis helped to determine the forms and types of relationships, as well as their strength. Regression analysis allowed us to define the parameters of the model, the statistical significance of the estimates, and to check the adequacy of the model qualityby the determination indicator, the value of which was estimated in the Fisher distribution tables.

The regression and correlation analysis is designed to test the significance of the state financial support for remote territories and the impact of it on the success of the region.

Seven Russian regions' data from 2010 to 2017 were used for the regression and correlation analysis. The indicators included:

1. The growth rate of the Gross regional product, $\%$ - as a dependent variable that reflects the economic success of the region;

2. The amount of gratuitous receipts from the Federal budget to the regional budget (million rubles).

3. The volume of public investment in the regional budget (million rubles). 
4. The state aid to the region (million rubles) - a combination of the previous two indicators.

\section{Result and Discussion}

The results of the study are in tables 1-3.

Table 1. Quantitative criteria for the ratio analysis of gratuitous receipts from the Federal budget (million rubles) and the rate of economic growth in the region (\%)

\begin{tabular}{|c|c|c|c|}
\hline $\begin{array}{c}\text { Name of the subject } \\
\text { of the Russian } \\
\text { Federation }\end{array}$ & $\begin{array}{c}\text { Correlation } \\
\text { coefficient }(\mathrm{r})\end{array}$ & $\begin{array}{c}\text { Coefficient of } \\
\text { determination } \\
\left(r^{2}\right), \%\end{array}$ & $\begin{array}{c}\text { Linear regression } \\
\text { equation }\end{array}$ \\
\hline Leningrad region & 0.271 & 7.35 & $\mathrm{y}=97.767+0.0005 \mathrm{x}$ \\
\hline Bryansk region & -0.601 & 36.18 & $\mathrm{y}=112.22-0.0004 \mathrm{x}$ \\
\hline Sakhalin region & 0.552 & 30.44 & $\mathrm{y}=96.845+0.0006 \mathrm{x}$ \\
\hline PrimorskyKrai & 0.501 & 25.09 & $\mathrm{y}=90.159+0.0005 \mathrm{x}$ \\
\hline Republic of Tuva & 0.232 & 5.39 & $\mathrm{y}=98.227+0.0003 \mathrm{x}$ \\
\hline Kamchatka territory & 0.565 & 31.96 & $\mathrm{y}=95.286+0.0002 \mathrm{x}$ \\
\hline Kaliningrad region & -0.275 & 7.55 & $\mathrm{y}=104.2-0.00004 \mathrm{x}$ \\
\hline
\end{tabular}

Table 2. Quantitative criteria for the ratio analysis of public investment in the regional budget (million rubles) and the economic growth rate of the region (\%)

\begin{tabular}{|c|c|c|c|}
\hline $\begin{array}{c}\text { Name of the subject } \\
\text { of the Russian } \\
\text { Federation }\end{array}$ & $\begin{array}{c}\text { Correlation } \\
\text { coefficient (r) }\end{array}$ & $\begin{array}{c}\text { Coefficient of } \\
\text { determination } \\
\left.r^{2}\right), \%\end{array}$ & $\begin{array}{c}\text { Linear regression } \\
\text { equation }\end{array}$ \\
\hline Leningrad region & 0.586 & 34.38 & $\mathrm{y}=95.017+0.0002 \mathrm{x}$ \\
\hline Bryansk region & 0.099 & 0.98 & $\mathrm{y}=103.26+0.0001 \mathrm{x}$ \\
\hline Sakhalin region & -0.565 & 31.87 & $\mathrm{y}=107.07-0.0008 \mathrm{x}$ \\
\hline PrimorskyKrai & 0.268 & 7.17 & $\mathrm{y}=99.75+0.00007 \mathrm{x}$ \\
\hline Republic of Tuva & 0.029 & 0.8 & $\mathrm{y}=102.27+0.0001 \mathrm{x}$ \\
\hline Kamchatka territory & 0.316 & 9.98 & $\mathrm{y}=99.916+0.0002 \mathrm{x}$ \\
\hline Kaliningrad region & -0.721 & 51.95 & $\mathrm{y}=107.0-0.0002 \mathrm{x}$ \\
\hline
\end{tabular}


Table 3. Quantitative criteria for the ratio analysis of the total amount of state aid to the region (million rubles) and the economic growth rate of the region (\%)

\begin{tabular}{|c|c|c|c|}
\hline $\begin{array}{c}\text { Name of the subject } \\
\text { of the Russian } \\
\text { Federation }\end{array}$ & $\begin{array}{c}\text { Correlation } \\
\text { coefficient }(\mathrm{r})\end{array}$ & $\begin{array}{c}\text { Coefficient of } \\
\text { determination } \\
\left(r^{2}\right), \%\end{array}$ & $\begin{array}{c}\text { Linear regression } \\
\text { equation }\end{array}$ \\
\hline Leningrad region & 0.606 & 36.72 & $\mathrm{y}=92.763+0.0002 \mathrm{x}$ \\
\hline Bryansk region & -0.609 & 37.13 & $\mathrm{y}=116.7-0.0005 \mathrm{x}$ \\
\hline Sakhalin region & 0.093 & 8.6 & $\mathrm{y}=100.59+0.00009$ \\
$\mathrm{x}$
\end{tabular}

A direct sufficient connection between the volume of public investment in regional budgets and the growth rate of GRP can be identified only in the Leningrad region $(\mathrm{r}=0.586)$, Kamchatka $(\mathrm{r}=0.316)$ and Primorye $(\mathrm{r}=0.268)$ regions, and in the Kaliningrad and Sakhalin regions, an inverse ratio was found ( $\mathrm{r}=-0.721$ and $\mathrm{r}=-0.565$, respectively).

When analysing the volume of gratuitous receipts from the Federal budget (million rubles) and the growth rate of GRP (\%) for the same period, we should highlight a positive ratio between these indicators in the Kamchatka territory $(\mathrm{r}=0.565)$, Primorsky territory $(\mathrm{r}=0.501)$, Sakhalin region $(\mathrm{r}=0.552)$, and Leningrad region $(\mathrm{r}=0.271)$. In the Kaliningrad and Bryansk regions, there is an inverse ratio $(\mathrm{r}=-0.275$ and $\mathrm{r}=-0.601$, respectively).

The ratioanalysis of public investment in the regional budget (RUB million), the volume of gratuitous receipts from the Federal budget (million RUB) and growth of GDP (\%) calculated by the regression equations shows that in five regions out of seven non-repayable receipts from the Federal budget have had a positive effect on GRP growth. Thus, in the Primorsky territory and the Leningrad region, the volume of subsidies of 1 billion rubles has increased the growth rate of GRP by $0.5 \%$, in Sakhalin region - by $0.6 \%$, in the Republic of Tyva - by $0.3 \%$, in the Kamchatka territory - by $0.2 \%$. When making public investments in the amount of 1 billion rubles there has been an increase in GRP growth rates in two regions by $0.2 \%$ (Leningrad region, Kamchatka territory), in three regions by about $0.1 \%$ (Bryansk region, the Republic of Tyva and Primorsky Krai), and in the Sakhalin and Kaliningrad regions - a decrease (by $0.8 \%$ and $0.2 \%$, respectively).

Analysing the connection of total aid to the regions (RUB m) and growth their GRP (\%) it should be noted that only two out of the seven regions have it significant between the studied indices (in the Leningrad region $\mathrm{r}=0.606$, this means that the growth rate of GRP by $36.72 \%$ is dependent on funding $\left(\mathrm{asr}^{2}=0.3672\right)$. In the Kamchatka region the correlation coefficient between these characteristics is 0.564 , hence the GRP growth by $31.75 \%$ is dependent on public investment $\left(\mathrm{r}^{2}=0.3175\right)$.

A significant connection can be said for the Republic of Tyva $(r=0.208,=0.0434)$ and Primorsky Krai $\left(\mathrm{r}=0.320, \mathrm{r}^{2}=0.1021\right)$.

A negative ratio is detected in the Kaliningrad and Bryansk regions $(r=-0.446$, $\mathrm{r}^{2}=0.1992$, and $\mathrm{r}=-0.609, \mathrm{r}^{2}=0.3713$, respectively), which indicates either poor-quality (poor) use of investment resources, or a long payback period for investments, or insufficient investments). 
At the same time, in regions with an upward trend and in fact, with the amount of assistance in 1 billion rubles, the GRP growth rate has increased in the range from $0.1 \%$ to $0.2 \%$. This is evidenced by the regression quations.

\section{Conclusions}

The results obtained suggest that the use of public financial resources as a tool for managing the development of regions and ensuring their sustainability is justified and generally leads to positive changes. In this case, this positive impact does not depend essentially from the kind of 'special areas' - as described above. The positive effect of growth of gross regional product from the state financial intervention appeared in one of the two investigated cross-border territories (Leningrad oblast), in one of the two coastal regions (Primorsky Krai), and in one of the two studied areas (Kamchatka).

The assessment of the results of using public financial resources to achieve sustainable development of regions should be based on an assessment of the results both for individual components of public financial flows, and on an assessment of the results of the total amount of financial resources sent to the regions. Moreover, the results deserve to be interpreted in a more thorough manner, provided that they come into a certain contradiction in different areas of research. Thus, as the study showed, the Republic of Tuva belongs to five regions out of seven in which gratuitous receipts from the Federal budget havehad a positive impact on the growth of GRP; however, in this region there is no direct sufficient connection between the volume of public investment and the growth rate of GRP.

Assessment of the impact of gratuitous receipts from the Federal budget may have different results if such an assessment is carried out for individual types of receipts (grants, subventions, subsidies), which is due to the different nature of each type. State subsidies due to their essential purpose, which is to increase the level of budgetary security of territories - will remain important and will be sent to the regions even if there are no noticeable positive changes in the level of socio-economic development. Therefore, changes in the socio-economic development of territories do not depend solely on subsidies. A more significant dependence will be characteristic of subsidies that are directed to the implementation of various joint projects of the state and territories, and, in addition, have a special purpose.

Public investment is not the only measure that affects the socio-economic development of territories. An equally important tool for improving the situation of regions is the adoption of state decisions on the creation of special territorial zones with a more favourable regime for economic activity. The effective functioning of special territorial zones helps to increase the rate of economic growth, increase revenues to the budgets of both territories and the state, reduce unemployment and stabilize the social situation in general. Special territorial zones can be considered as 'growth drivers' [6].

State participation in the development of territories through public investment should be based on the use of the existing potential of administrative-territorial units, in particular, the credit potential of local banking systems [7] and supplemented by appropriate measures aimed at stimulating investment by the territorial authorities. We emphasize that active investment should be an integral part of the economic policy of any territorial unit of any country, not just the Russian Federation. In particular, stimulating the development of territories through investment is extremely important for agricultural territories, including in the context of growing demand for a healthy environment and healthy nutrition [8]. 


\section{References}

1. V. V. Oznamets, International Electronic scientific and Practical Journal «The State Counsellor», 2 (2018)

2. M.Yu. Kalinchikov, Regional economy: theory and practice, 9 (2005)

3. D.E. Morkovkin, Moscow Witte University Bulletin, Series 1: Economics and Management, 1 (2014)

4. N.V. Voroshilov, E.S. Gubanova, Economic and Social Changes: Facts, Trends, Forecast, 11 (6) (2018)

5. Z. Zivanovic, D.R. Gataric, Bulletin of Geography-Socio-Economic Series, 35 (2017)

6. S. D. Bodrunov, The Manager, 9 (1) (2018)

7. K. Indus, Baltic Journal of Economic Studies, 4 (3)

8. B. Rivza, M. Kruzmetra, Proceeding of the 2018 International Scientific Conference Economic Sciences for Agribusiness and Rural Economy, 1(2018) 